\title{
Tandem repeat DNA: applications in mutation analysis
}

\author{
Carole Yauk* and Aris Polyzos
}

Environmental and Occupational Toxicology Division, Health Canada, Ottawa, ON, Canada K1A 0L2

\begin{abstract}
Summary
Non-coding tandem repeat DNA sequences have high rates of mutation that facilitate the measurement of induced mutation in small sample sizes. It has been suggested that these loci may be useful biomarkers for heritable genetic mutation induced by exposure to genotoxic agents. Significant induction of mutation is quantifiable in the germline of mice exposed to mutagens. The primary focus of this work has been on exposure to radiation. The data suggest that meiosis or DNA replication/repair may be required for induction of mutation in the germline at tandem repeats. Mutations arise via indirect mechanisms rather than by direct damage to the repeat locus itself, therefore reflecting genomic instability rather than targeted DNA damage. These markers have also been used to measure induced germline mutations in animals exposed to ambient levels of urban air pollution. The mutagenicity is associated with particulate matter in the air but the exact chemical nature of the mutagens is unknown. Lack of knowledge of the relationship between ESTR instability and gene mutation, and lack of understanding of the mechanisms resulting in instability prevent inference on the health-related implications of induced tandem repeat mutation. We have developed single-molecule PCR approaches to study ESTR instability in vitro. This method circumvents the requirement of sub-cloning and allows for many more individual ESTR alleles to be examined. These types of laboratory-based experiments will be crucial in clarifying the types of chemicals that can generate tandem repeat instability and thereby provide insight into the mechanisms of action and the putative mutagens found in complex environmental matrices.
\end{abstract}

Keywords: germline mutation, tandem repeat DNA, minisatellites, ESTRs, genetic instability, induced mutation

The study of heritable mutation is extremely difficult given the very low rate of mutation in eukaryotic germ cells. Distinguishing differences in mutation rate between populations is more likely if highly variable DNA regions are examined. To date, the most variable regions identified in the genome are tandemly repeated DNA sequences. Repeat types used for the study of induced mutation include microsatellites, expanded simple tandem repeats (ESTRs) and minisatellite DNA (Table 1) (reviewed in (Yauk, 2004)). The tandem repeat regions utilized in studies on induced mutagenesis are predomi-

\footnotetext{
${ }^{*}$ E-mail: Carole_Yauk@hc-sc.gc.ca

Correspondence to: Carole L. Yauk, Environmental Health

Centre, Health Canada, Tunney's Pasture, P.L. 0803A, Ottawa,

ON, Canada, K1A 0L2

Received: March 3, 2005, accepted: March 3, 2005

(C) Japanese Environmental Mutagen Society
}

nantly located in non-coding regions of the genome. Therefore, these regions have lower rates of DNA repair and are not under selective pressure. Furthermore, long stretches of simple tandem repeat tracts are intrinsically unstable due to polymerase slippage and the formation of complex structures. These properties combine to result in repeat loci having exceptionally high mutation rates compared to unique sequence DNA and make them valuable tools for the study of induced mutation in relatively small sample sizes.

Unstable minisatellites $(10-100 \mathrm{bp}$ repeat units) have baseline rates of mutation in the germline that range from $10^{-4}$ to nearly $100 \%$ for the most variable locus (Berg et al., 2003; Jeffreys et al., 1997). The mechanism of male germline mutation in typical human minisatellites is predominantly associated with recombination and gene con- 
Table 1 Some general characteristics of tandem repeat loci (reviewed in (Ellegren 2004; Jeffreys et al. 1997; Yauk 2004))

\begin{tabular}{llll}
\hline & Microsatellites & ESTRs & Minisatellites \\
\hline $\begin{array}{l}\text { Length of repeat units } \\
\text { Length of alleles }\end{array}$ & $1-6 \mathrm{bp}$ & $4-10 \mathrm{bp}$ & $10-100 \mathrm{bp}$ \\
Effect of variant repeats & $10 \mathrm{bp}-1 \mathrm{~kb}$ & $1-20 \mathrm{~kb}$ & $1-20 \mathrm{~kb}$ \\
& Decreases mutation rate & Decreases mutation rate & $\begin{array}{l}\text { Variable-variant repeats typical in } \\
\text { highly unstable minisatellites } \\
\text { much more stable in than germline }\end{array}$ \\
$\begin{array}{l}\text { Somatic mutation } \\
\begin{array}{l}\text { Principle hypothesized mecha- } \\
\text { nism of mutation }\end{array}\end{array}$ & $\begin{array}{l}\text { Unstable } \\
\text { Replication/secondary confor- } \\
\text { mation }\end{array}$ & $\begin{array}{l}\text { Unstable } \\
\text { Replication/repair }\end{array}$ & $\begin{array}{l}\text { Recombination/gene conversion for } \\
\text { unstable alleles }\end{array}$ \\
& Unstable in most eukaryotes & $\begin{array}{l}\text { Highly unstable in mice; no } \\
\text { data for other species }\end{array}$ & $\begin{array}{l}\text { Can be highly unstable in humans; } \\
\text { much more stable in mice, pigs; differ- } \\
\text { ent mutation mechanism in mice than } \\
\text { humans }\end{array}$ \\
\hline
\end{tabular}

Table 2 Summary of human germline minisatellite studies

\begin{tabular}{|c|c|c|c|}
\hline Population & $\begin{array}{l}\text { Type of exposure and experimental } \\
\text { approach* }\end{array}$ & Effect on minisatellite mutation & References \\
\hline $\begin{array}{l}\text { Hiroshima } \\
\text { /Nagasaki }\end{array}$ & Single acute exposure; pedigree & $\begin{array}{l}\text { No significant increase in any min- } \\
\text { isatellites examined }\end{array}$ & $\begin{array}{l}\text { (Kodaira et al. 2004; Satoh et } \\
\text { al. 1996) }\end{array}$ \\
\hline Chernobyl & $\begin{array}{l}\text { Chronic low-dose internal and exter- } \\
\text { nal; pedigree }\end{array}$ & $\begin{array}{l}\text { Significant increase at several loci; } \\
\text { increase with dose }\end{array}$ & $\begin{array}{l}\text { (Dubrova et al. 1996; Dubro- } \\
\text { va et al. 1997) }\end{array}$ \\
\hline Chernobyl & $\begin{array}{l}\text { Chronic low-dose internal and exter- } \\
\text { nal; pedigree }\end{array}$ & $\begin{array}{l}\text { Significant increase in offspring } \\
\text { born after the accident compared to } \\
\text { siblings born before }\end{array}$ & (Dubrova et al. 2002b) \\
\hline Chernobyl clean-up workers & $\begin{array}{l}\text { Fractionated external exposures; } \\
\text { pedigree }\end{array}$ & No significant increase & $\begin{array}{l}\text { (Kiuru et al. 2003; Livshits et } \\
\text { al. 2001; Slebos et al. 2004) }\end{array}$ \\
\hline $\begin{array}{l}\text { Semipalatinsk nuclear test } \\
\text { site }\end{array}$ & $\begin{array}{l}\text { Chronic contamination downwind of } \\
\text { test site; pedigree }\end{array}$ & $\begin{array}{l}\text { Significant increase in offspring } \\
\text { born after testing; frequency } \\
\text { decreasing with time in keeping } \\
\text { with decay of radionuclides in the } \\
\text { area. }\end{array}$ & (Dubrova et al. 2002a) \\
\hline $\begin{array}{l}\text { Human sperm samples fol- } \\
\text { lowing chemotherapy or } \\
\text { radiotherapy }\end{array}$ & $\begin{array}{l}\text { Chemotherapeutic drugs known to } \\
\text { have various adverse effects on } \\
\text { germ cells; mantle, abdominal and } \\
\text { hemipelvic radiotherapy; sperm PCR }\end{array}$ & $\begin{array}{l}\text { Fifteen men analyzed in total with } \\
\text { variable stages of spermatogenesis. } \\
\text { No significant increase, but high } \\
\text { variability among patients. }\end{array}$ & $\begin{array}{l}\text { (Armour et al. 1999; May et } \\
\text { al. 2000; Zheng et al. 2000) }\end{array}$ \\
\hline
\end{tabular}

\footnotetext{
${ }^{*}$ Mutations may be scored either in pedigrees by comparing minisatellite allele sizes in offspring to maternal and paternal allele sizes
} (Pedigree) or by PCR amplification of DNA in sperm (sperm PCR)

version events, although less is known about more stable loci (Jeffreys et al., 1994). Minisatellites have been used to study induced mutation arising in humans exposed to high environmental concentrations of radioactive pollutants or undergoing chemo- and/or radio-therapy (Table 2). The results of these studies are conflicting. Several experiments have shown that continuous chronic internal/external exposure in humans can result in transmission of minisatellite mutations to offspring. However, studies on human males exposed directly to radiotherapy or chemotherapy yield contradictory findings, possibly due to the nature of the exposure. Discrepancies likely exist given the vastly different types of exposures examined including chronic low-dose internal exposure, acute single exposures and fractionated external exposures. Additionally, numerous confounders influence studies in humans, including potential genetic differences between individuals and populations among other extraneous environmental variables. Clearly, animal studies are required to clarify the events leading to induced tandem repeat mutation, to study the mechanisms involved, and to resolve discrepancies in the human investigations.

The majority of work examining induced instability in laboratory mice has been on mutation arising at ESTRs in males exposed to radiation. There are many inconsistencies among the findings from different laboratories (Table $3)$. The majority of the studies carried out rely on a pedigree-based approach to quantify germline mutation arising in the offspring of exposed males. Questions remain regarding the stage of spermatogenesis that is most sensitive to mutagen exposure. The majority of the data indicate that the pre-meiotic stages of spermatogenesis are the most responsive (Barber et al., 2000; Dubrova et al., 
Table 3 Summary of laboratory experiments on expanded simple tandem repeat instability

\begin{tabular}{|c|c|c|c|}
\hline Exposure & Stage & Response & References \\
\hline $\begin{array}{l}\text { X-rays, } \gamma \text {-radiation, fission neu- } \\
\text { trons }(0-2 \mathrm{~Gy})\end{array}$ & $\begin{array}{l}\text { Pre-meiotic through post-mei- } \\
\text { otic }\end{array}$ & $\begin{array}{l}\text { Linear dose-response; pre-meiotic sen- } \\
\text { sitive; no response in late stage } \\
\text { (exposure } 3 \text { weeks before mating } \\
\text { only) }\end{array}$ & $\begin{array}{l}\text { (Dubrova et al. 1993; Dubrova } \\
\text { et al. 2000; Dubrova et al. 1998; } \\
\text { Somers et al. 2004b; Yauk et al. } \\
\text { 2002) }\end{array}$ \\
\hline $\begin{array}{l}\gamma \text {-radiation, fission neutrons } \\
(1-3 \mathrm{~Gy})\end{array}$ & $\begin{array}{l}\text { Pre-meiotic through post-mei- } \\
\text { otic }\end{array}$ & $\begin{array}{l}\text { Spermatids most responsive } \\
(2-3 \text { weeks prior to mating) }\end{array}$ & $\begin{array}{l}\text { (Fan et al. 1995; Sadamoto et } \\
\text { al. 1994) }\end{array}$ \\
\hline $\begin{array}{l}252 \mathrm{Cf} \text { radiation } \\
\text { (35\% } \gamma \text {-rays; } 65 \% \text { neutrons) } \\
(0.35-1.02 \mathrm{~Gy})\end{array}$ & $\begin{array}{l}\text { Pre-meiotic through post-mei- } \\
\text { otic }\end{array}$ & $\begin{array}{l}\text { Spermatids most responsive } \\
\text { ( } 2 \text { weeks prior to mating) }\end{array}$ & (Niwa et al. 1996) \\
\hline $\begin{array}{l}\text { PCBs (Aroclor } 1254 ; 100 \\
\mathrm{mg} / \mathrm{kg})\end{array}$ & Pre- and post-meiotic & Slight induction; post-meiotic only & (Hedenskog et al. 1997) \\
\hline Diesel exhaust extract & Pre- and post-meiotic & No response & (Hedenskog et al. 1997) \\
\hline Cisplatin $(10 \mathrm{mg} / \mathrm{kg})$ & Pre-meiotic and meiotic & No response & (Barber et al. 2000) \\
\hline $\begin{array}{l}\text { Ethylnitrosourea } \\
(0-75 \mathrm{mg} / \mathrm{kg})\end{array}$ & Pre- and post-, and meiotic & Linear-plateau; pre-meiotic stages & (Vilarino-Guell et al. 2003) \\
\hline iPMS (0-37.5 mg/kg) & Pre- and post-, and meiotic & Linear-plateau; pre-meiotic stages & (Vilarino-Guell et al. 2003) \\
\hline Etoposide (80 mg/kg) & Pre- and post-, and meiotic & $\begin{array}{l}\text { Mutation induction at meiotic stages } \\
\text { only }\end{array}$ & (Vilarino-Guell et al. 2003) \\
\hline
\end{tabular}

1993; 1998; 2000; Somers et al., 2004b; Vilarino-Guell et al., 2003; Yauk et al., 2002). Exposure of pre-meiotic spermatogonial stem cells to radiation is also known to result in mutation arising directly in sperm as measured by PCRbased approaches (Yauk et al., 2002). However, work by Niwa et al., (Fan et al., 1995; Niwa et al., 1996; Sadamoto et al., 1994) repeatedly demonstrates that post-meiotic irradiation (2 weeks prior to mating) is most effective at inducing tandem repeat mutation. This time point has not been investigated in other laboratories. As spermatozoa lack DNA metabolism capabilities, one proposed explanation for these discrepancies is that the measured mutations arise in the zygote shortly after fertilization rather than in sperm at this time point (Niwa, 2003). Therefore, these mutations are not the result of germline mutation, but rather destabilization of the genome in early embryogenesis. Research on stage-specificity would greatly benefit from the application of PCR-based approaches to measure induced mutation in sperm at various stages of development and in somatic tissues during embryogenesis. Furthermore, the experiments to date have been carried out across several different strains of mice. Genetic background may significantly influence both spontaneous and induced mutation rates (Barber et al., 2002; 2004; Dubrova, 2005). Therefore, there are many gaps in the knowledge and much more work is needed in order to begin to resolve these issues.

Despite the variability in findings across laboratories, studies using ESTRs clearly demonstrate that exposure of male mice to radiation results in germline ESTR instability. Furthermore, the induced instability does not result directly from DNA lesions at the repeat loci, but rather results from indirect effects (Dubrova, 2005; Dubrova et al., 1993; 1998; Yauk et al., 2002). For example, the predicted numbers of strand breaks expected to result from a given exposure to radiation, combined with knowledge of locus size, allows the calculation of number of strand breaks across the observed locus. The data demonstrate that the estimate of DNA damage at the locus cannot explain the high frequency of induced mutation and therefore mutation is not exclusively the result of targeted events at the locus. The mechanism operating in induced mutation remains elusive, but may result from cellular response to mutagenic lesions in DNA (Barber et al., 2004). This applies to radiation exposure, but there is very little data for chemical mutagens.

Although several studies have examined the exposure of animals to urban air pollutants (Somers et al., 2002; 2004a; Yauk et al., 2000; Yauk and Quinn 1996), very few have characterized individual mutagen effects in vivo. To date, the mutagens examined include two alkylating agents, one topoisomerase inhibitor and one cross-linking agent (Table 3 ). These chemicals initiate very different types of DNA lesions, but each is capable of generating strand breaks either directly or through DNA repair or replication. If strand breaks are the important lesions for inducing non-targeted mutation at tandem repeat loci, then any agent capable of inducing strand breaks should also induce tandem repeat instability. The two alkylating agents, ethylnitrosourea (ENU) and isopropyl methanesulfonate (iPMS), show a remarkable similarity to radiation in the stage-specificity of ESTR mutation induction, with mutations arising exclusively in pre-meiotic stem cells (Vilarino-Guell et al., 2003). In contrast, etoposide acts on a very defined stage of spermatogenesis, exclusively targeting meiotic spermatocytes (weeks 4 and 5 after exposure) (Vilarino-Guell et al., 2003). In contrast, 


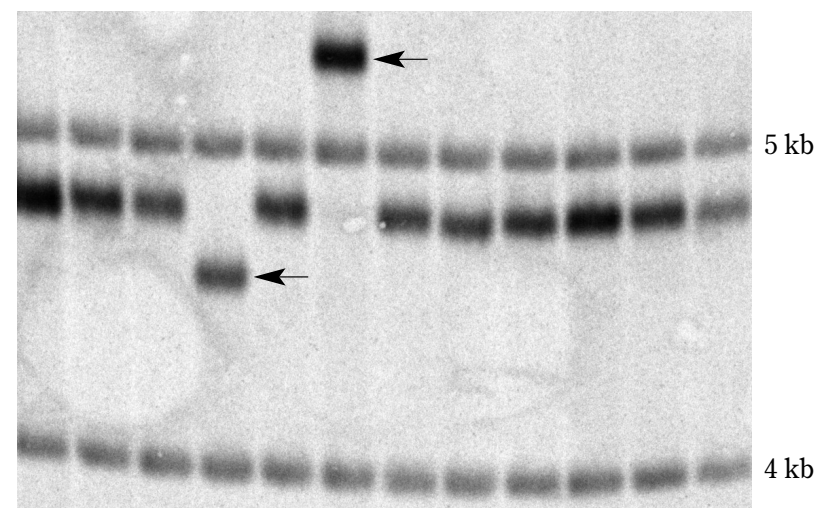

Fig. 1 Gel of SM-PCR of the ESTR Ms6-hm in murine C3H10T1/2 cells. Each lane contains on average on single amplified alleles of Ms6-hm. Forty centimeter $0.8 \%$ agarose gels were run until the $2 \mathrm{~kb}$ internal marker was at the end of the gel. Internal $1 \mathrm{~kb}$ markers are indicated beside the gel. Two mutants (one deletion and one gain) are indicated with arrowheads.

the DNA cross-linking agent cisplatin does not cause an increase in ESTR instability at any of the time points analyzed (Barber et al., 2000). Therefore, although DNA strand breaks are potential outcomes of exposure to each of these agents, the mutagens operate under different modes of action and ESTR response may be lesion-specific (rather than global response to the presence of DNA strand breaks). Much more work is needed to understand how chemicals exhibiting different modes of action influence the outcome of ESTR instability. Furthermore, the mechanism of induced mutation and its relationship to gene mutation clearly needs to be resolved before the biological implications of tandem repeat mutation can be understood.

Tandem repeat instability has been investigated in animals exposed to ambient levels of industrial/urban air pollution in the field. In the first study, herring gulls nesting in areas on the Canadian Great Lakes of varying distances from steel mills were examined. The measured minisatellite mutation frequencies in the offspring of herring gulls was inversely correlated with proximity to integrated steel mills (Yauk et al., 2000; Yauk and Quinn, 1996). It was unclear whether mutation results from exposure predominantly through the diet or through inhalation of air pollutants at the industrial sites. Therefore, in order to investigate the contribution of air pollution in more detail, mice were caged $1 \mathrm{~km}$ from the steel mills for 10 weeks or kept at a rural reference site outside the city (Somers et al., 2002). Pre-meiotic stages of spermatogenesis were examined by mating mice 6 weeks after the exposure period. A significant increase in paternal mutation was measured in mice at the steel location. A follow-up study found that the increased mutation rate resulted from exposure to contaminated particulate matter in the air from that environment (Somers et al., 2004a). Removal of particles by high- efficiency particulate-air filtration resulted in a decrease of mutation back to the reference levels. This study is currently being repeated using PCR based approaches to measure mutation arising directly in the sperm of $\mathrm{F} 1$ mice (C57B1/CBA) and characterizing amounts of DNA adducts in gametes across the exposure period.

The experiments described above were the first to demonstrate that current ambient levels of air pollution may pose a genetic hazard. However, our understanding of the biological consequences of increased tandem repeat mutation is unclear. How repeat sequence instability relates to gene sequence mutation or to other measures of toxicity, and therefore the potential human health consequences of destabilized tandem repeat DNA, are unknown.

A detailed analysis of the types of chemicals that can induce tandem repeat instability in mice would be of great benefit to this field of research. In order to carry out a comprehensive comparison, we are currently developing methods to study ESTR instability in vitro. Current approaches used to study tandem repeat instability in vitro rely on sub-cloning individual somatic cells from exposed cultures, and are labour intensive (e.g., (Boyd et al., 2000; Nakagama et al., 1997)). We are using singlemolecule PCR (Yauk et al., 2002) to amplify individual molecules from different somatic mouse cell cultures exposed to mutagens with different modes of action (Fig. 1). Currently, studies are being carried out to optimize cell culture conditions for mutation analysis and to determine the number of population doublings required to measure significant changes in mutation frequencies. Proof of principle is being established by selecting mutagens known to destabilize ESTRs in the germline. Our preliminary investigations demonstrate that the level of confluence in contact-inhibited mouse mesenchymal cell lines has a significant effect on mutation frequency and preliminary work with ENU suggests that ESTRs in somatic cells in vitro may provide a good model for induced instability in the germline (but perhaps only relevant to replicating pre-meiotic stem cells; manuscript in preparation). Chemicals with different modes of action and cell lines with various genetic backgrounds will be used to discern potential mechanisms involved in tandem repeat destabilization.

In summary, much research is still required before any defined relationship can be drawn between potential genetic hazard and induced tandem repeat instability. The loci under examination do not themselves result in any observed phenotypes and therefore induced mutation confers no known adverse outcome or decline in fitness. It remains to be seen how tandem repeat instability correlates with, or is predictive of events that do lead to genetic disease. However, many tandem repeats, from microsatel- 
lites through to minisatellites, are known to be associated with genes and could influence gene function (e.g., see (Wren et al., 2000)). Furthermore, recent work in canines suggests that tandem repeat DNA has played a significant role in accelerated evolutionary adaptation, on top of selective breeding, in dogs (Fondon and Garner, 2004). The authors suggest that differences in the lengths of certain genes involved in development played a large role in morphological differences among breeds, indicating the potential importance of tandem repeat DNA in evolution. With such possible evolutionary consequences, the induction of tandem repeat instability in general should not be ignored in the context of genetic hazard.

\section{Acknowledgements}

We would like to thank Iain Lambert and Craig Parfett for helpful comments on the manuscript. Research was funded by the Health Canada Genomics R \& D fund.

\section{References}

Armour, J.A., M.H. Brinkworth and A. Kamischke (1999) Direct analysis by small-pool PCR of MS205 minisatellite mutation rates in sperm after mutagenic therapies, Mutat. Res., 445, 73-80.

Barber, R., M. Plumb, A.G. Smith, C.E. Cesar, E. Boulton, A.J. Jeffreys and Y.E. Dubrova (2000) No correlation between germline mutation at repeat DNA and meiotic crossover in male mice exposed to X-rays or cisplatin, Mutat. Res., 457, 79-91.

Barber, R., M.A. Plumb, E. Boulton, I. Roux and Y.E. Dubrova (2002) Elevated mutation rates in the germ line of first- and second-generation offspring of irradiated male mice, Proc. Natl. Acad. Sci. USA, 99, 6877-6882.

Barber, R.C., L. Miccoli, P.P. van Buul, K.L. Burr, A. van DuynGoedhart, J.F. Angulo and Y.E. Dubrova (2004) Germline mutation rates at tandem repeat loci in DNA-repair deficient mice, Mutat. Res., 554, 287-295.

Berg, I., R. Neumann, H. Cederberg, U. Rannug and A.J. Jeffreys (2003) Two modes of germline instability at human minisatellite MS1 (locus D1S7): complex rearrangements and paradoxical hyperdeletion, Am. J. Hum. Genet., 72, 1436-1447.

Boyd, M., A. Livingstone, L.E. Wilson, E.M. Marshall, A.G. McCluskey, R.J. Mairs and T.E. Wheldon (2000) Dose-response relationship for radiation-induced mutations at micro- and minisatellite loci in human somatic cells in culture, Int. J. Radiat. Biol., 76, 169-176.

Dubrova, Y.E. (2005) Radiation-induced mutation at tandem repeat DNA Loci in the mouse germline: spectra and doubling doses, Radiat. Res., 163, 200-207.

Dubrova, Y.E., R.I. Bersimbaev, L.B. Djansugurova, M.K. Tankimanova, Z. Mamyrbaeva, R. Mustonen, C. Lindholm, M. Hulten and S. Salomaa (2002a) Nuclear weapons tests and human germline mutation rate, Science, 295, 1037.

Dubrova, Y.E., G. Grant, A.A. Chumak, V.A. Stezhka and A.N. Karakasian (2002b) Elevated minisatellite mutation rate in the post-chernobyl families from ukraine, Am. J. Hum. Genet., 71, 801809.

Dubrova, Y.E., A.J. Jeffreys and A.M. Malashenko (1993) Mouse minisatellite mutations induced by ionizing radiation, Nat. Genet.,
5, 92-94.

Dubrova, Y.E., V.N. Nesterov, N.G. Krouchinsky, V.A. Ostapenko, R. Neumann, D.L. Neil and A.J. Jeffreys (1996) Human minisatellite mutation rate after the Chernobyl accident, Nature, 380, 683-686.

Dubrova, Y.E., V.N. Nesterov, N.G. Krouchinsky, V.A. Ostapenko, G. Vergnaud, F. Giraudeau, J. Buard and A.J. Jeffreys (1997) Further evidence for elevated human minisatellite mutation rate in Belarus eight years after the Chernobyl accident, Mutat. Res., 381, 267278.

Dubrova, Y.E., M. Plumb, J. Brown, E. Boulton, D. Goodhead and A.J. Jeffreys (2000) Induction of minisatellite mutations in the mouse germline by low-dose chronic exposure to gamma-radiation and fission neutrons, Mutat. Res., 453, 17-24.

Dubrova, Y.E., M. Plumb, J. Brown, J. Fennelly, P. Bois, D. Goodhead and A.J. Jeffreys (1998) Stage specificity, dose response and doubling dose for mouse minisatellite germ-line mutation induced by acute radiation, Proc. Natl. Acad. Sci. USA, 95, 62516255.

Ellegren, H (2004) Microsatellites, simple sequences with complex evolution, Nat. Rev. Genet., 5, 435-445.

Fan, Y.J., Z. Wang, S. Sadamoto, Y. Ninomiya, N. Kotomura, K. Kamiya, K. Dohi, R. Kominami and O. Niwa (1995) Dose-response of a radiation induction of a germline mutation at a hypervariable mouse minisatellite locus, Int. J. Radiat. Biol., 68, 177-183.

Fondon, J.W., 3rd and H.R. Garner (2004) Molecular origins of rapid and continuous morphological evolution, Proc. Natl. Acad. Sci. USA, 101, 18058-18063.

Hedenskog, M., M. Sjogren, H. Cederberg and U. Rannug (1997) Induction of germline-length mutations at the minisatellites PC-1 and PC-2 in male mice exposed to polychlorinated biphenyls and diesel exhaust emissions, Environ. Mol. Mutagen., 30, 254-259.

Jeffreys, A.J., P. Bois, J. Buard, A. Collick, Y. Dubrova, C.R. Hollies, C.A. May, J. Murray, D.L. Neil, R. Neumann, J.D. Stead, K. Tamaki and J. Yardley (1997) Spontaneous and induced minisatellite instability, Electrophoresis, 18, 1501-1511.

Jeffreys, A.J., K. Tamaki, A. MacLeod, D.G. Monckton, D.L. Neil and J.A. Armour (1994) Complex gene conversion events in germline mutation at human minisatellites, Nat. Genet., 6, 136-145.

Kiuru, A., A. Auvinen, M. Luokkamaki, K. Makkonen, T. Veidebaum, M. Tekkel, M. Rahu, T. Hakulinen, K. Servomaa, T. Rytomaa and R. Mustonen (2003) Hereditary minisatellite mutations among the offspring of Estonian Chernobyl cleanup workers, Radiat. Res., 159, 651-655.

Kodaira, M., S. Izumi, N. Takahashi and N. Nakamura (2004) No evidence of radiation effect on mutation rates at hypervariable minisatellite loci in the germ cells of atomic bomb survivors, Radiat. Res, 162, 350-356.

Livshits, L.A., S.G. Malyarchuk, S.A. Kravchenko, G.H. Matsuka, E.M. Lukyanova, Y.G. Antipkin, L.P. Arabskaya, E. Petit, F. Giraudeau, P. Gourmelon, G. Vergnaud and B. Le Guen (2001) Children of chernobyl cleanup workers do not show elevated rates of mutations in minisatellite alleles, Radiat. Res., 155, 74-80.

May, C.A., K. Tamaki, R. Neumann, G. Wilson, G. Zagars, A. Pollack, Y.E. Dubrova, A.J. Jeffreys and M.L. Meistrich (2000) Minisatellite mutation frequency in human sperm following radiotherapy, Mutat. Res., 453, 67-75.

Nakagama, H., S. Kaneko, H. Shima, H. Inamori, H. Fukuda, R. Kominami, T. Sugimura and M. Nagao (1997) Induction of minisatellite mutation in NIH 3T3 cells by treatment with the tumor promoter okadaic acid, Proc. Natl. Acad. Sci. USA, 94, 1081310816. 
Niwa, O. (2003) Induced genomic instability in irradiated germ cells and in the offspring; reconciling discrepancies among the human and animal studies, Oncogene, 22, 7078-7086.

Niwa, O., Y.J. Fan, M. Numoto, K. Kamiya and R. Kominami (1996) Induction of a germline mutation at a hypervariable mouse minisatellite locus by $252 \mathrm{Cf}$ radiation, J. Radiat. Res. (Tokyo), 37, 217224.

Sadamoto, S., S. Suzuki, K. Kamiya, R. Kominami, K. Dohi and O. Niwa (1994) Radiation induction of germline mutation at a hypervariable mouse minisatellite locus, Int. J. Radiat. Biol., 65, 549-557.

Satoh, C., N. Takahashi, J. Asakawa, M. Kodaira, R. Kuick, S.M. Hanash and J.V. Neel (1996) Genetic analysis of children of atomic bomb survivors, Environ Health Perspect, 104 Suppl 3, 511-519.

Slebos, R.J., R.E. Little, D.M. Umbach, Y. Antipkin, T.D. Zadaorozhnaja, N.A. Mendel, C.A. Sommer, K. Conway, E. Parrish, S. Gulino and J.A. Taylor (2004) Mini-and microsatellite mutations in children from Chernobyl accident cleanup workers, Mutat. Res., 559, 143-151.

Somers, C.M., B.E. McCarry, F. Malek and J.S. Quinn (2004a) Reduction of particulate air pollution lowers the risk of heritable mutations in mice, Science, 304, 1008-1010.

Somers, C.M., R. Sharma, J.S. Quinn and D.R. Boreham (2004b) Gamma radiation-induced heritable mutations at repetitive DNA loci in out-bred mice, Mutat. Res., 568, 69-78.

Somers, C.M., C.L. Yauk, P.A. White, C.L. Parfett and J.S. Quinn (2002) Air pollution induces heritable DNA mutations, Proc. Natl. Acad. Sci. USA, 99, 15904-15907.
Vilarino-Guell, C., A.G. Smith and Y.E. Dubrova (2003) Germline mutation induction at mouse repeat DNA loci by chemical mutagens, Mutat. Res., 526, 63-73.

Wren, J.D., E. Forgacs, J.W. Fondon, 3rd, A. Pertsemlidis, S.Y. Cheng, T. Gallardo, R.S. Williams, R.V. Shohet, J.D. Minna and H.R. Garner (2000) Repeat polymorphisms within gene regions, phenotypic and evolutionary implications, Am. J. Hum. Genet., 67, 345-356.

Yauk, C.L. (2004) Advances in the application of germline tandem repeat instability for in situ monitoring, Mutat. Res., 566, 169-182.

Yauk, C.L., Y.E. Dubrova, G.R. Grant and A.J. Jeffreys (2002) A novel single molecule analysis of spontaneous and radiation-induced mutation at a mouse tandem repeat locus, Mutat. Res., 500, 147156.

Yauk, C.L., G.A. Fox, B.E. McCarry and J.S. Quinn (2000) Induced minisatellite germline mutations in herring gulls (Larus argentatus) living near steel mills, Mutat. Res., 452, 211-218.

Yauk, C.L. and J.S. Quinn (1996) Multilocus DNA fingerprinting reveals high rate of heritable genetic mutation in herring gulls nesting in an industrialized urban site, Proc. Natl. Acad. Sci. USA, 93, 12137-12141.

Zheng, N., D.G. Monckton, G. Wilson, F. Hagemeister, R. Chakraborty, T.H. Connor, M.J. Siciliano and M.L. Meistrich (2000) Frequency of minisatellite repeat number changes at the MS205 locus in human sperm before and after cancer chemotherapy, Environ. Mol. Mutagen., 36, 134-145. 